\title{
Tapu ve Kadastro Programlarının Power Testi ile İncelenmesi, Ardanuç Örneği
}

\author{
Selim TAŞKAYA ${ }^{1 *}$ \\ ${ }^{1}$ Artvin Çoruh Üniversitesi, Mimarlık ve Şehir Planlama Bölümü, Artvin, Türkiye \\ *selim_taskaya@artvin.edu.tr
}

\begin{abstract}
Özet
Ülkemizde 2020 yılı Yükseköğretim Kurulu verilerine göre, 26 üniversitede hali hazırda öğrenci almış olan tapu ve kadastro programı, tapu ve sicil müdürlükleri ile lisanslı harita ve kadastro bürolarına önlisans seviyede ara eleman yetiştirmek üzere, meslek yüksekokulları, mimarlık ve şehir planlama bölümünde faaliyetini sürdürmektedir. Her bölüm ve programda olduğu gibi, doygunluk seviyesine ulaştığında, arz talep ilişkisi neticesinde programa kayıt yaptıran öğrenci sayısı düşecektir. 2020 yılı Yükseköğretim Kurulu kararları neticesinde okul birincileri hariç, toplam 1230 kişilik öğrenci alım kontenjanı, ilgili 26 üniversitelere verilmiş, tüm kontenjan dolmuştur. Tapu ve Kadastro programlarının ne kadar süre daha bu şekilde doluluk oranının devam edeceği incelenmiştir. 40 öğrenci kontenjanından 35 ine kayıt yaptıran Artvin Ardanuç Tapu ve Kadastro öğrencilerine çeşitli sorular sorularak, programın ne kadar daha popüler olabileceği, ne zaman iş durumun azalabileceği, ne kadar süre daha devam edebileceği araştırılmaya çalışıımıştır. Power analizi ile $\% 95$ güven ve $\% 5$ kabul edilebilir hata ile çalışmada 35 öğrenciye göre örneklem sayıları belirlenmiş ve test güven ve güç oranlarına göre, anket sonuçlarından toplam alınan 1230 kontenjanda minimum bulunması gereken kişi sayıları tespit edilmiştir.
\end{abstract}

Anahtar Kelimeler: Tapu ve Kadastro, Ardanuç, PowerTesti

\section{GiRiş}

Ülkemizde genç nüfusun fazla olması, açılan üniversite sayısının artması, toplumun eğitim düzeyinin yükselmesi dolayısıyla üniversitelere girmek isteyen öğrenci sayısını artırmıştır [3]. Öğrenciler tarafından sıklıkla tercih edilen meslek yüksekokulları bugüne kadar birçok süreçten geçmiştir. 1950'li yıllarda tekniker okullar ile başlayan süreç yüksek tekniker okulları, ön lisans okulları, yay-kur meslek yüksekokulları ve son olarak günümüzdeki meslek yüksekokulları haline ulaşarak yetiştirdiği öğrencilerle ülkemizin ara eleman ihtiyacını karşılamaktadır. Tapu, diğer ifadeyle tapu senetleri herhangi bir taşınmazın ilgili malik ya da maliklere ait olduğunu gösteren resmi belgedir. 6083 sayılı tapu ve kadastro genel müdürlüğü teşkilat ve görevleri hakkında kanun da belirtilmiştir. Kadastro ise, 3402 say1lı Kadastro kanunu çerçevesinde tüm arazilerin sınırlarının belirlenmesidir [12]. Tapu sicil müdürlüklerinde, tapu senetlerinin onayı, yevmiye defterlerine her türlü taşınmazın tüm bilgilerinin işlenmesi yapılmaktadır. Kadastro 
müdürlüklerinde ise, arazi üzerindeki dataların alınıp, sayısal veya digital olarak değerlendirilip, paftalara aktarım işlemlerinin yapılması neticesinde, bu ana hat ekseninde işlemler, Tapu ve Kadastro Genel Müdürlüğü çatısı altında, bölge müdürlükleri, bunlara bağlı kadastro müdürleri ve kadastro şefliklerinde sürdürülmektedir [12]. Ülkemizde genç nüfusun fazla olması, açılan üniversite sayısının artması, toplumun eğitim düzeyinin yükselmesi dolayısıyla üniversitelere girmek isteyen öğrenci sayısını artırmıştır [3]. Öğrenciler tarafından sıklıkla tercih edilen meslek yüksekokulları bugüne kadar birçok süreçten geçmiştir. 1950'li yıllarda tekniker okullar ile başlayan süreç yüksek tekniker okulları, ön lisans okulları, yay-kur meslek yüksekokulları ve son olarak günümüzdeki meslek yüksekokulları haline ulaşarak yetiştirdiği öğrencilerle ülkemizin ara eleman ihtiyacını karşılamaktadır [4]. Günümüzde meslek yüksekokulları çok sayıda bölüm ve program ile birçok sektör için nitelikli eleman yetiştirmek amaçlı eğitim öğretime devam etmektedir [2].

\section{TAPU ve KADASTRO PROGRAMLARI}

Ülkemizde 2019-2020 eğitim öğretim yılında, 13 üniversitede 905 kontenjan ile öğrenci almıştır. 20202021 eğitim öğretim y1lında ise 26 üniversite 1230 kontenjan ile Tapu ve Kadastro programı, meslek yüksekokulları mimarlık ve şehir planlama bölümü altında faaliyet göstermektedir. Harita Kadastro programlarından farkı, saha değil de ofis elemanı yetiştirmektir. Ön lisans seviyede, 2 y1l 4 dönemden oluşmaktadır. Üniversitelerin kendi senato kararlarına göre, ortalama 120 akts, 15 şer günlük 2 staj döneminden program oluşmaktadır. Harita Kadastro programının aksine arazi ve ölçme üzerine verilen, teorik ve pratik ders sayısı azdır. Dersler, tapu sicil uygulamaları, tapu mevzuatı, hukuk ve hukukun türleri olan borçlar, miras, kadastro hukuku kapsamında yürütülmektedir. Ayrıca, taşınmaz değerleme, imar ve şehircilik uygulamaları, kamulaştırma, kentsel dönüşüm, arazi yönetimi ve planlaması, ölçme bilgisi dersleri de öğrencilere verilmektedir [13].

Tablo 1. 2020-2021 yılı üniversitelerin ön lisans program kontenjan, taban puanları ve başarı sıralamaları [14].

\section{ÜNIVERSITELER}

\begin{tabular}{|c|c|c|c|c|c|}
\hline $\begin{array}{r}\text { AYDIN ADNAN MENDERES } \\
\text { ÜNIVERSITTESİ (Devlet Üniversitesi) }\end{array}$ & $\begin{array}{r}\text { Tapu ve } \\
\text { Kadastro (İÖ) }\end{array}$ & TYT & 40 & 247,92603 & 952689 \\
\hline $\begin{array}{l}\text { KAHRAMANMARAŞ SÜTÇÜ } \\
\text { İMAM ÜNIVERSITESİ (Devlet } \\
\text { Üniversitesi) }\end{array}$ & $\begin{array}{r}\text { Tapu ve } \\
\text { Kadastro (İÖ) }\end{array}$ & TYT & 50 & 244,57958 & 992936 \\
\hline $\begin{array}{c}\text { MANISA CELÂL BAYAR } \\
\text { ÜNIVERSITTESİ (Devlet Üniversitesi) }\end{array}$ & $\begin{array}{r}\text { Tapu ve } \\
\text { Kadastro (İÖ) }\end{array}$ & TYT & 40 & 235,74185 & 1099227 \\
\hline $\begin{array}{l}\text { BURDUR MEHMET AKİ } \\
\text { ERSOY ÜNIVERSITESİ (Devlet } \\
\text { Üniversitesi) }\end{array}$ & $\begin{array}{r}\text { Tapu ve } \\
\text { Kadastro (İÖ) }\end{array}$ & TYT & 40 & 233,3491 & 1128004 \\
\hline $\begin{array}{l}\text { UŞAK ÜNIVERSİTESİ (Devlet } \\
\text { Üniversitesi) }\end{array}$ & $\begin{array}{r}\text { Tapu ve } \\
\text { Kadastro (İÖ) }\end{array}$ & TYT & 40 & 230,77956 & 1158908 \\
\hline $\begin{array}{l}\text { ANKARA HACI BAYRAM VELİ } \\
\text { ÜNIVERSITESİ (Devlet Üniversitesi) }\end{array}$ & $\begin{array}{l}\text { Tapu ve } \\
\text { Kadastro }\end{array}$ & TYT & 60 & 284,0104 & 597526 \\
\hline
\end{tabular}




\author{
KAHRAMANMARAŞ SÜTÇÜ \\ İMAM ÜNIVERSITESİ (Devlet \\ Üniversitesi) \\ AYDIN ADNAN MENDERES \\ ÜNIVERSITTESİ (Devlet Üniversitesi) \\ SELÇUK ÜNIVERSITESİ \\ (KONYA) (Devlet Üniversitesi)
}

\author{
Tapu ve \\ Kadastro \\ Tapu ve
Kadastro
Tapu ve
Kadastro
}

(ANTALYA) (Devlet Üniversitesi)

\section{MUĞLA SITKI KOÇMAN}

ÜNIVERSITTESİ (Devlet Üniversitesi)

NIĞDE ÖMER HALISDEMIR ÜNIVERSITTESİ (Devlet Üniversitesi)

MANİSA CELÂL BAYAR ÜNIVERSITTESİ (Devlet Üniversitesi)

BURDUR MEHMET AKİF ERSOY ÜNIVERSITESİ (Devlet Üniversitesi)

PAMUKKALE ÜNIVERSITESİ (DENIZLI) (Devlet Üniversitesi)

TOKAT GAZİOSMANPAŞA ÜNIVERSITTESİ (Devlet Üniversitesi)

TEKİRDAĞ NAMIK KEMAL ÜNIVERSİTESİ (Devlet Üniversitesi)
BARTIN ÜNIVERSITESİ (Devlet Üniversitesi)

HİTİT ÜNIVERSITTESİ (ÇORUM) (Devlet Üniversitesi)

BITTLIS EREN ÜNIVERSITTESI

(Devlet Üniversitesi)

YOZGAT BOZOK

ÜNIVERSİTESİ (Devlet Üniversitesi)

UŞAK ÜNIVERSITTESİ (Devlet Üniversitesi)

FIRAT ÜNIVERSITESİ (ELAZIĞ) (Devlet Üniversitesi)

\section{Kadastro}

Tapu ve

Kadastro

Tapu ve

Kadastro

Tapu ve

Kadastro

Tapu ve

Kadastro

Tapu ve

Kadastro

Tapu ve

Kadastro

Tapu ve

Kadastro

Tapu ve

Kadastro

Tapu ve

Kadastro

Tapu ve

Kadastro

Tapu ve

Kadastro

Tapu ve

Kadastro

Tapu ve

Kadastro
TYT

40

255,12134

873716

TYT

TYT

TYT

45

259,84472

823885

760275

880412

889355

TY

50

251,04238

916748

TYT

50

249,18735

937519

TYT

30

249,15614

937895

TYT

40

248,77944

942425

TYT

35

248,55089

945174

TYT

30

247,49146

957915

TYT

40

245,04424

987348

TYT

40

242,2844

1020540

TYT

40

240,8246

1038097

TYT

60

240,79538

1038449

TYT

30

240,77816

1038656 


\section{ARTVIN ÇORUH ÜNIVERSITESI \\ (Devlet Üniversitesi)}

KÜTAHYA DUMLUPINAR

ÜNIVERSITESİ (Devlet Üniversitesi)

GÜMÜŞHANE ÜNIVERSITESI

(Devlet Üniversitesi)

ERZINCAN BINAALI YILDIRIM

ÜNIVERSITESİ (Devlet Üniversitesi)

IĞDIR ÜNIVERSITESİ (Devlet

\begin{tabular}{|c|c|c|c|c|}
\hline $\begin{array}{l}\text { Tapu ve } \\
\text { Kadastro }\end{array}$ & TYT & 40 & 234,90636 & 1109275 \\
\hline $\begin{array}{l}\text { Tapu ve } \\
\text { Kadastro }\end{array}$ & TYT & 40 & 234,72683 & 1111434 \\
\hline $\begin{array}{l}\text { Tapu ve } \\
\text { Kadastro }\end{array}$ & TYT & 40 & 231,6479 & 1148464 \\
\hline $\begin{array}{l}\text { Tapu ve } \\
\text { Kadastro }\end{array}$ & TYT & 50 & 229,79847 & 1170989 \\
\hline $\begin{array}{l}\text { Tapu ve } \\
\text { Kadastro }\end{array}$ & TYT & 40 & 227,89188 & 1196587 \\
\hline
\end{tabular}

Tablo 1. den görüleceği gibi, temel yeterlilik testi sonucu, en yüksek ve en düşük YGS 6 puanı ile üniversitelerin Tapu ve Kadastro programları taban ve tavan puanları oluşmuştur. Tablo 1. deki üniversitelere, 2020-2021 eğitim öğretim y1lında Muğla Sttk1 Koçman, Pamukkale, Alanya Alaaddin Keykubat, Çankırı Karatekin, Bartın Üniversiteleri de programı açmaya çalışmış ve bir kısmı programı açmıştır [14].

\section{ARTVIN ÇORUH ÜNIVERSITESI ARDANUÇ TAPU ve KADASTRO PROGRAMI ÖĞRENCILERI ÜZERINE BİR ARAŞTIRMA}

Artvin Çoruh Üniversitesi, Artvin Meslek Yüksekokulu, Ardanuç Tapu ve Kadastro Programı, diğer üniversitelerde program az bulunduğundan ve öğrenci talebinin fazla olacağ 1 düşüncesi ile 2018 y1lı Mart üniversite senatosu sonucunda dosyası oluşturulmuş, Yükseköğretim Kuruluna gönderilip, kurulun onayı sonucunda 2018-2019 eğitim öğretim yılında 41 öğrenci kontenjanı ile açılmıştır [13].

20 erkek 15 kız öğrencinin kayıt yaptırması ile eğitim öğretim hayatına başlamıştır. 35 öğrenciye program ile ilgili sorular sorulmuştur. 35 öğrenci üzerinden, toplam 1230 öğrencinin kısmi düşüncesi, tapu ve kadastro programlarının çalışanları olacak bu kişilerin mesleği nasıl idame ettirebileceği düşüncesi araştırılmaya çalışılmıştır. Deneysel, kuramsal örneklem ile bir standart sapmada homojen yaklaşık tahmin edinildi [10].

1-)Tapu ve Kadastro Programına, bilinçli bir şekilde bilerek mi geldiniz? 


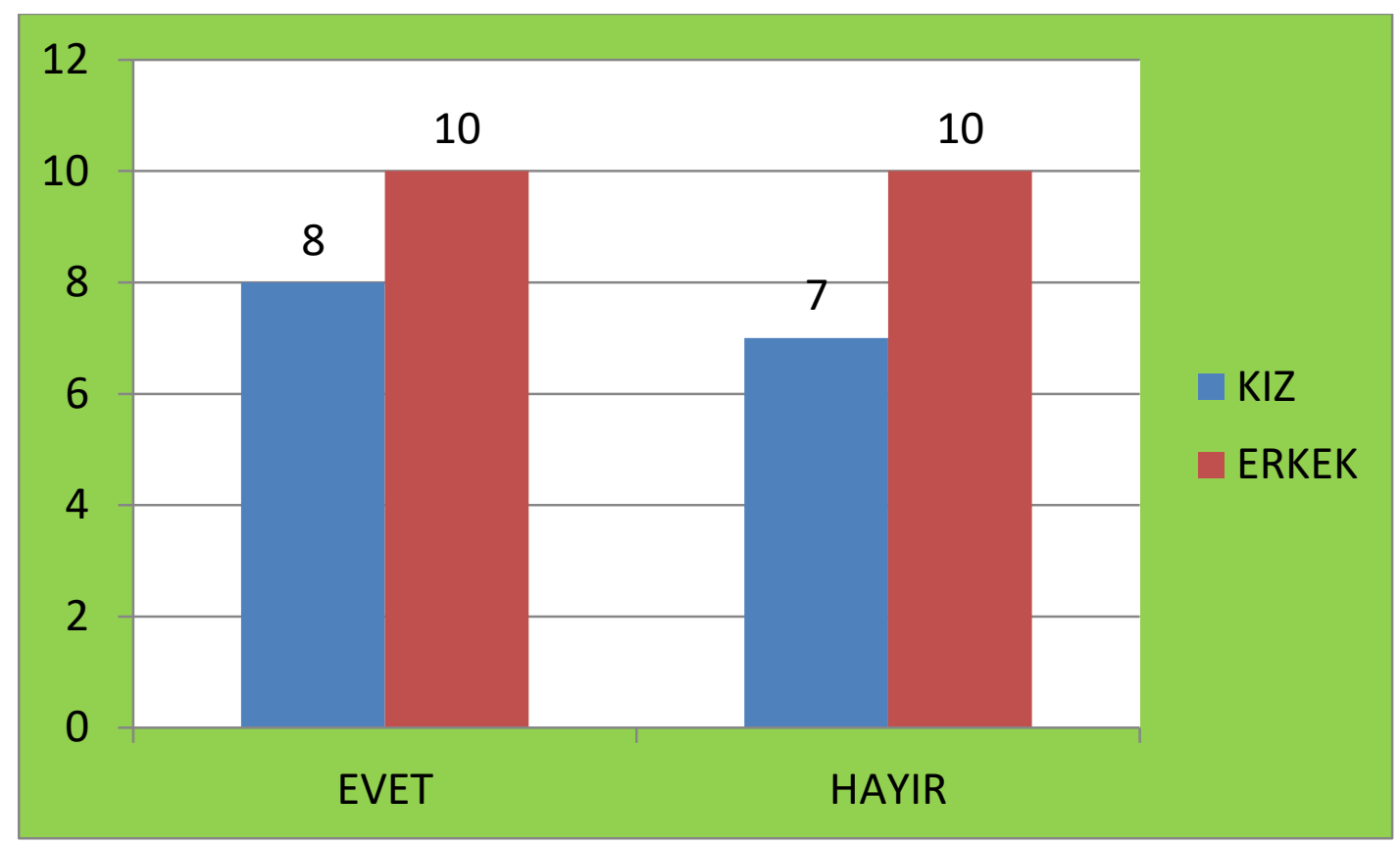

Şekil 1. Evet ya da hayır erkek ve kız öğrenci sayısı

Şekil 1. de tapu ve kadastro programına, bilinçli bir şekilde mi girdiniz sorusuna, kız öğrencilerden 8 i evet, 7 si hayır cevabını vermiş, erkek öğrencilerin ise $10 \mathrm{u}$ evet, $10 \mathrm{u}$ hayır cevabını vermiştir. Yani, hem kız hem de erkek öğrencilerin yarısı seçtikleri mesleği bilmeden, sadece puanlarının yettiği program olduğundan seçmiştir.

2-) Tapu ve Kadastro Programına kayıt yaptırıp dersler başlayınca, kararınızın doğruluğu ya da yanlışlığı hakkındaki fikirleriniz ne oldu?

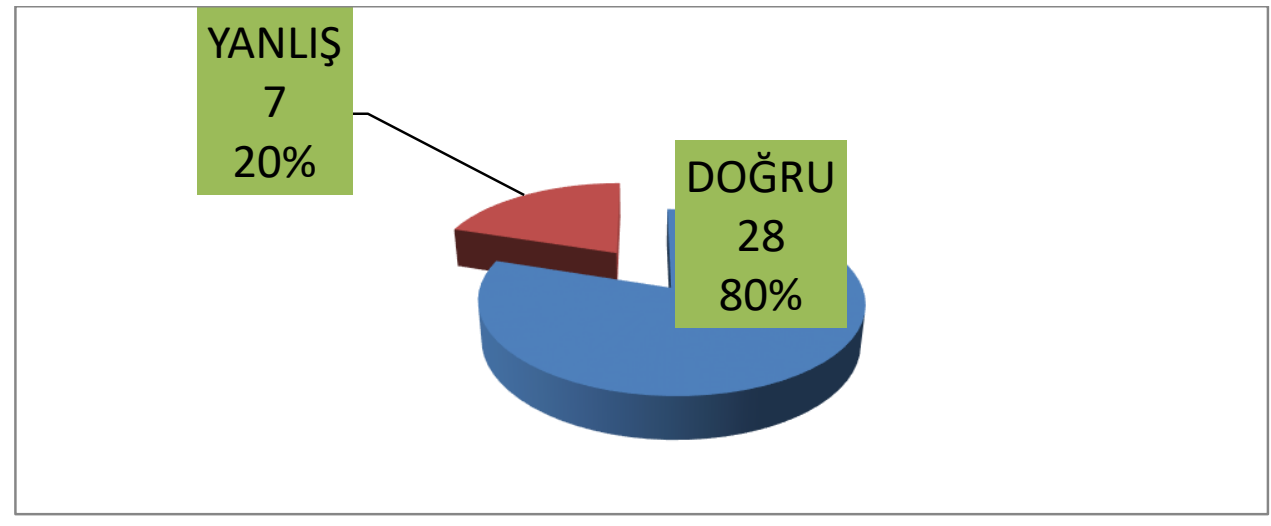

Şekil 2. Toplam doğru veya yanlış cevap veren öğrenci sayısı

Şekil 2. de öğrencilere programa başladıklarında kararlarının doğruluğu ya da yanlışlığı hakkında ne düşündükleri sorulduğunda, 28 kişinin doğru, 7 kişinin ise yanlış olduğu cevabı alınmıştır. \%80 i doğru olduğunu belirtmiştir.

3-) Sizce, Tapu ve Kadastro programlarının çoğu üniversitede açılması, meslek ve iş hayatını nasıl etkiler? 


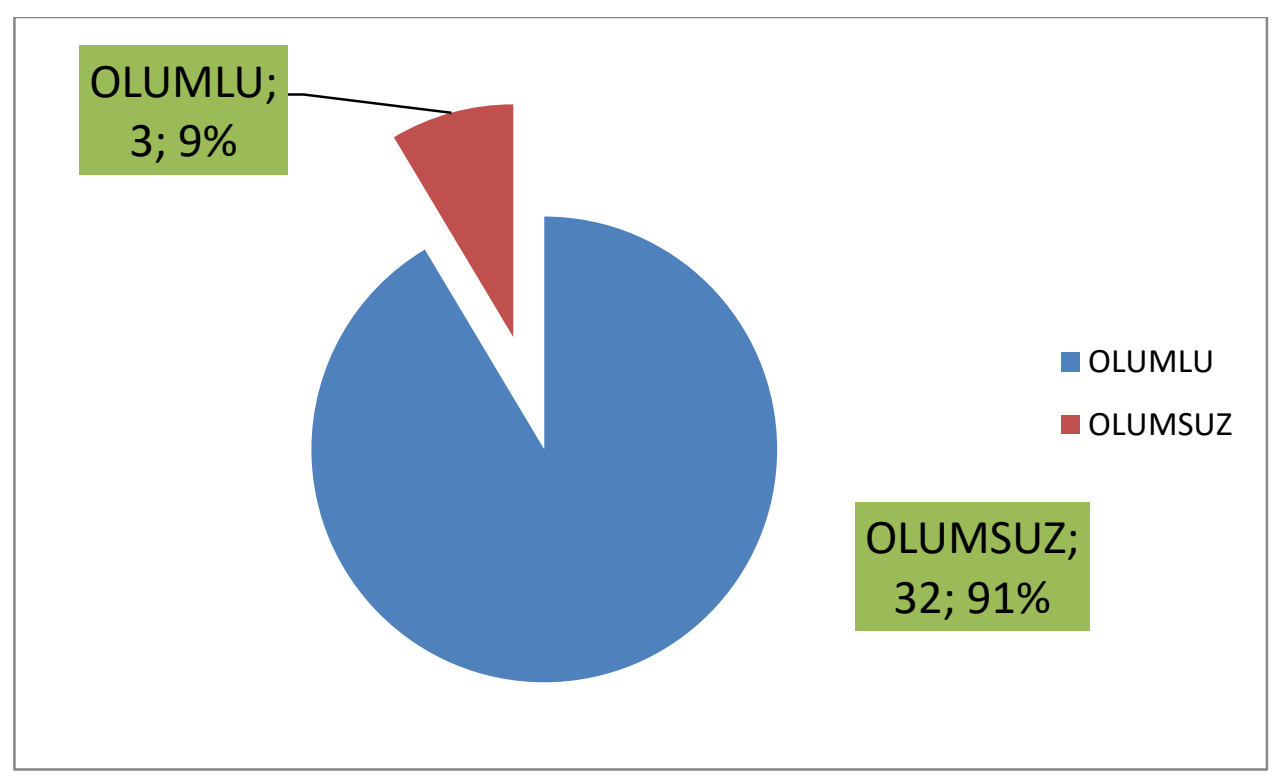

Şekil 3. Toplam olumlu veya olumsuz cevap sayıs1

Şekil 3. de, öğrencilere programın çeşitli üniversitelerde açılmasının, iş hayatına yansımasının nasıl olacağı sorusu sorulmuş, \% $91 \mathrm{i}$ olumsuz, $\% 9 \mathrm{u}$ ise olumlu görüş bildirmiştir. Yani, öğrenciler mezun sayısının artışının, işsizlik oranının artacağını düşünmektedir.

4-) Tapu ve Kadastro programı, sizce ne kadar süre daha popülerliğini sürdürebilir?

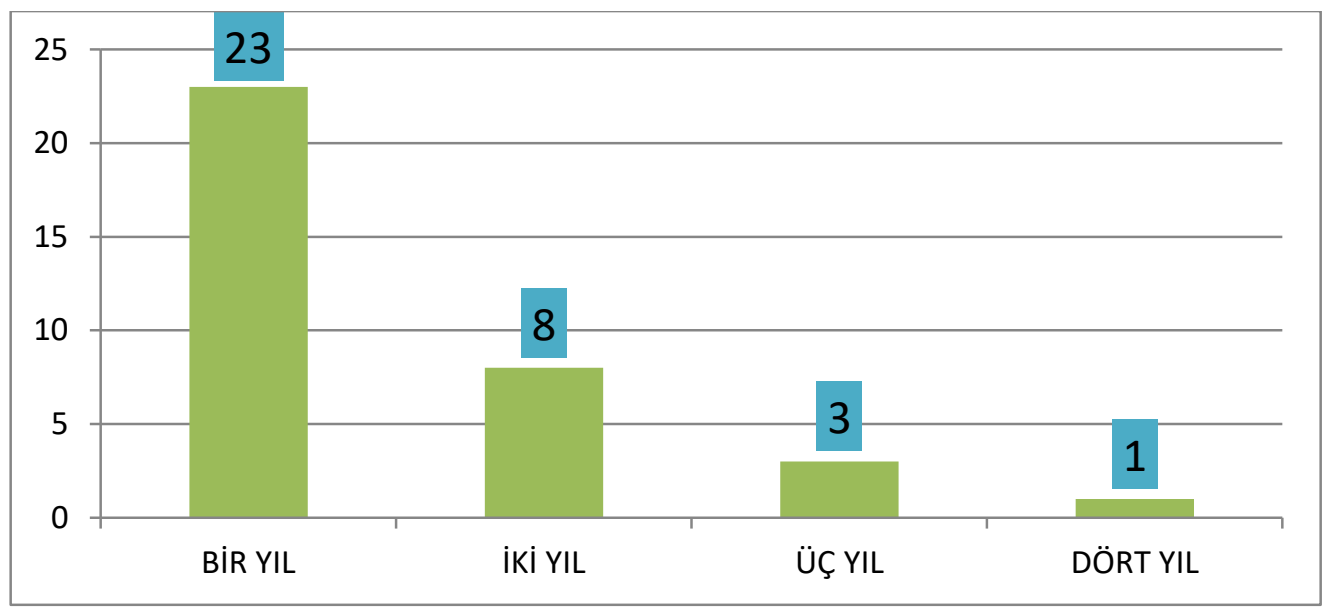

Şekil 4. Öğrencilerin verdikleri yıllara göre yanıtları

Şekil 4. de, 35 kişiden 23 ü bir yıl, 8 i iki yıl, 3 ü üç y1l, 1 i ise dört yıl sonra daha tapu ve kadastro programının doyum noktasına ulaşacağı görüşünde bulunmuştur.

5-) Tapu ve Kadastro programı, KPSS atamalarında en son 77 puan ile memur aldığına göre, sizce 2020 KPSS ile puanlarda nasıl bir değişim olur? 


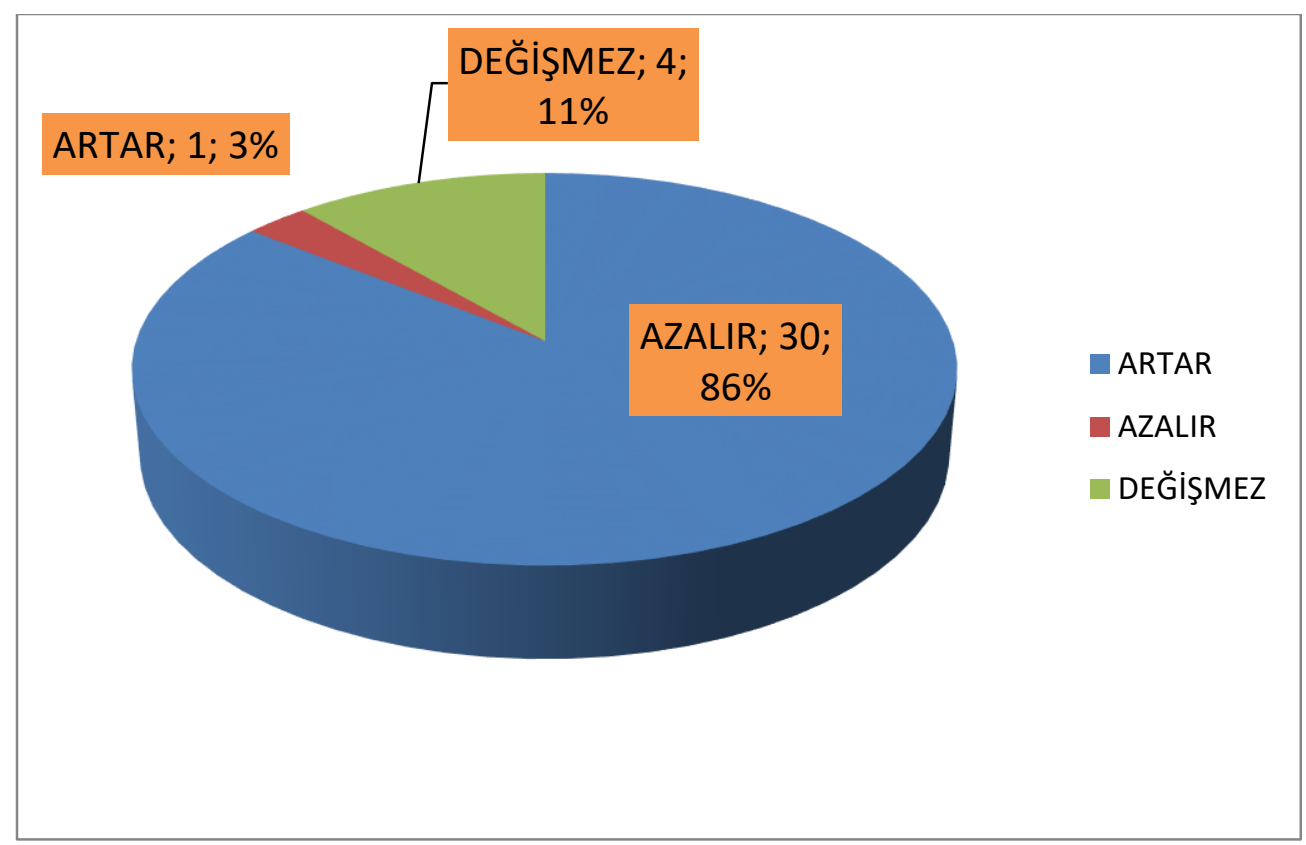

Şekil 5. Öğrencilerin, KPSS deki puanların değişim yanıtları

Şekil 5. de teknik kadro alımlarında 2 yılda bir ön lisans seviyede KPSS yapıldığından, mezun sayısının artmasına da bağlı olarak, memur alımlarının nasıl oranda olabileceği sorusu sorulduğunda öğrencilerin \%86 s1 azalacağını, \%11 i değişmeyeceğini, \%1 i ise artacağg görüşünü belirtmiştir.

6-) Programdaki derslerden en çok size hangisinin katkısı olduğunu düşünüyorsunuz? 


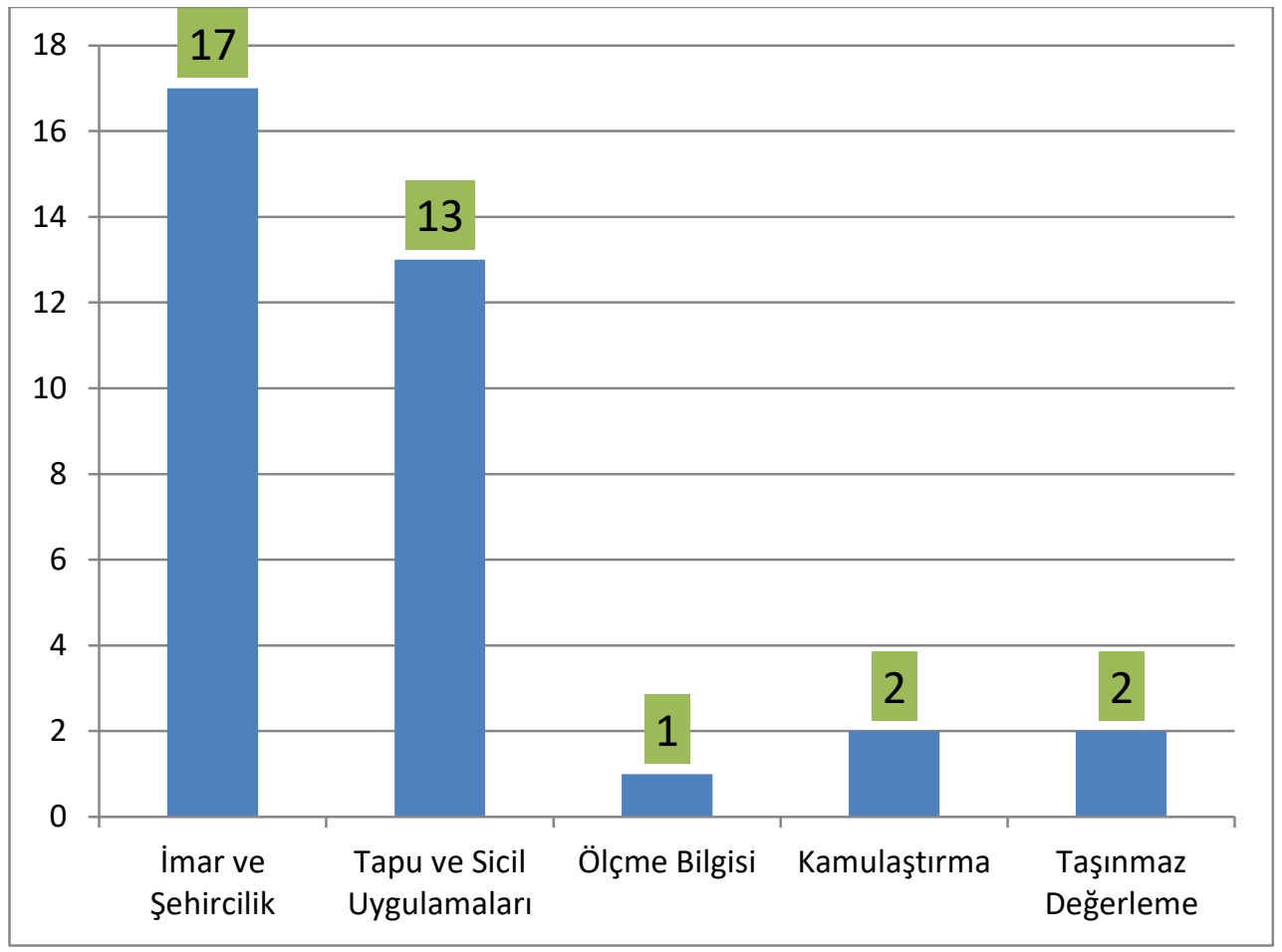

Şekil 6. Öğrencilerin dersler hakkındaki yanıtları

Şekil 6. da, öğrenciler en çok imar ve şehircilik ile tapu ve sicil uygulamaları derslerinin mesleki yaşamalarına katkısı olacağını düşünmüştür.

7-) Programdan mezun olduktan sonra, DGS ile lisansa tamamlamayı düşünüyor musunuz?

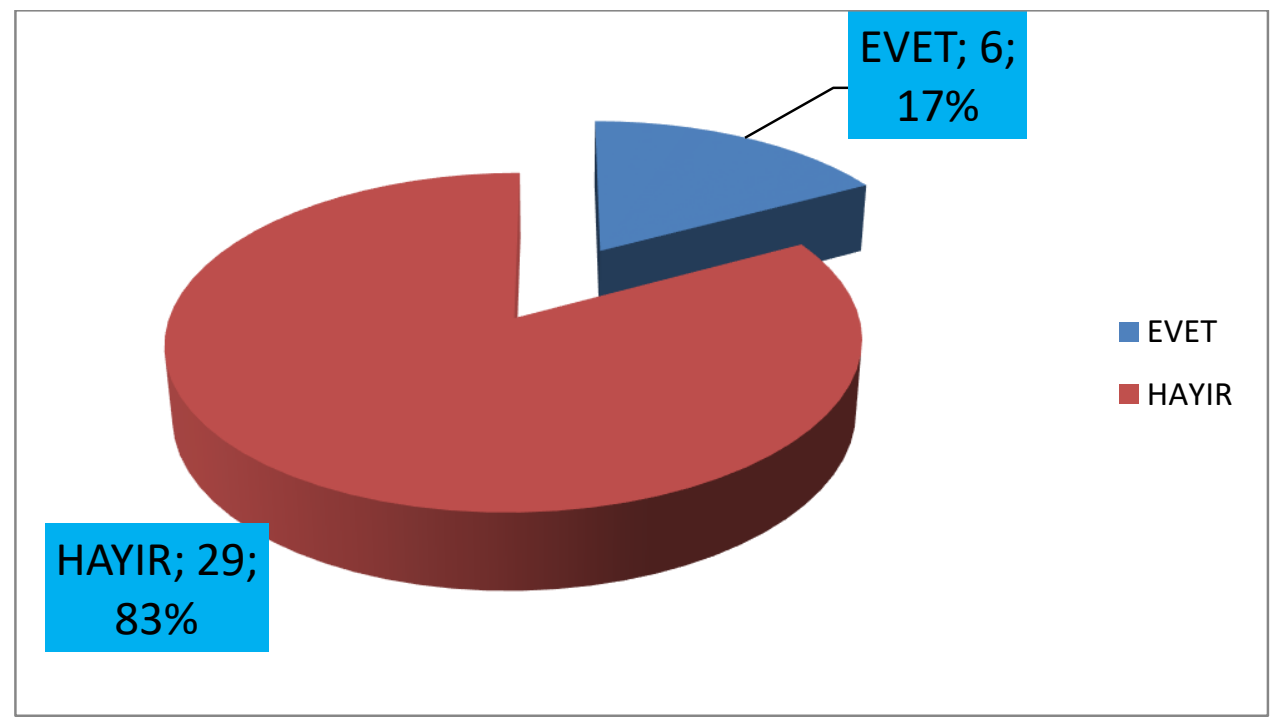

Şekil 7. DGS ile geçiş sorusunun öğrenci yanıtları 
Şekil 7. de, 4 yıllık mühendislik programlarına geçmeyi düşünen sadece 6 kişi ile \%17 lik bir öğrenci sayısı ortaya çıkmıştır.

8-) Sizce, Harita Kadastro değil de, Tapu ve Kadastro ön lisans programını neden tercih ettiniz?

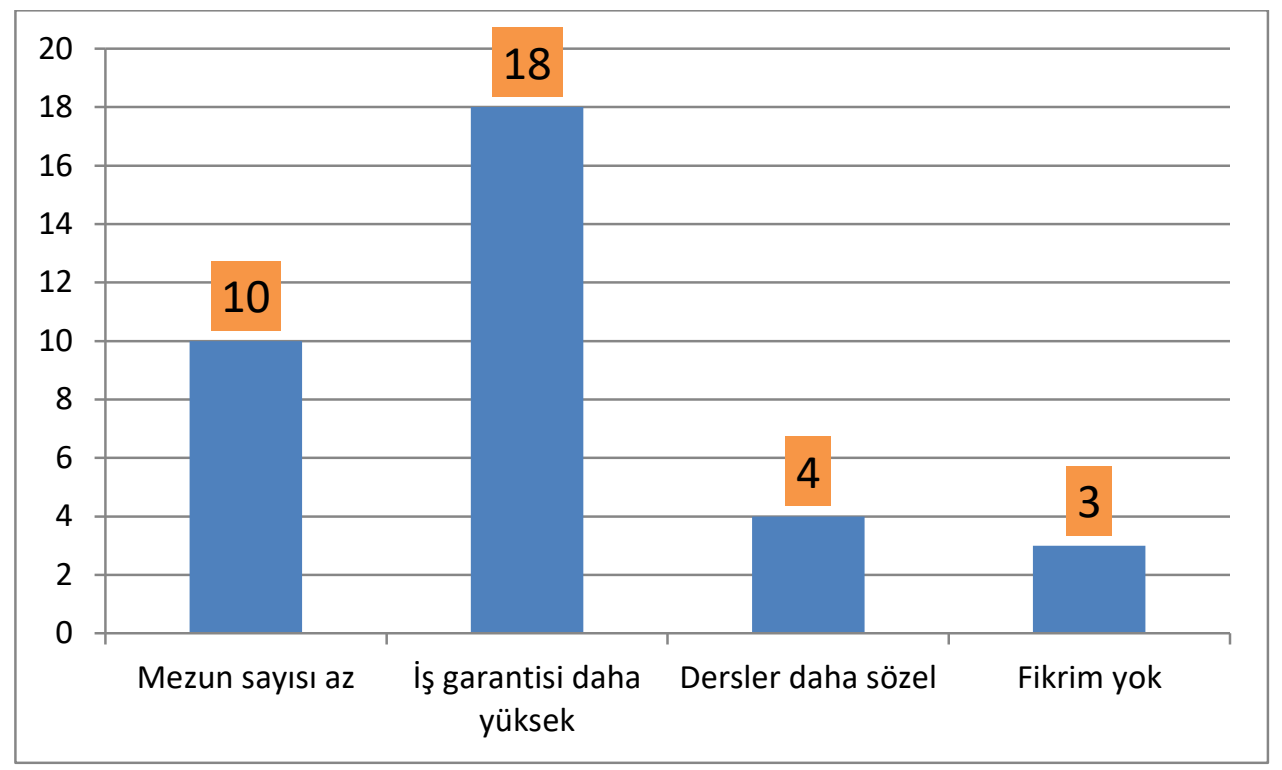

Şekil 8. Program tercihi sorusu öğrenci yanıtları

Şekil 8. de, öğrencilerin Harita Kadastro 2 yıllık programı değil de, Tapu ve Kadastroyu tercih etmesinin sebebinin 18 kişiden de anlaşılacağı gibi iş garantisini daha yüksek görmeleridir. Ardından, mezun sayısının az olması da, ikinci etken olduğu görülmektedir.

9-) Sizce, mezun sayısının artmaması için program kontenjanları düşürülmeli midir?

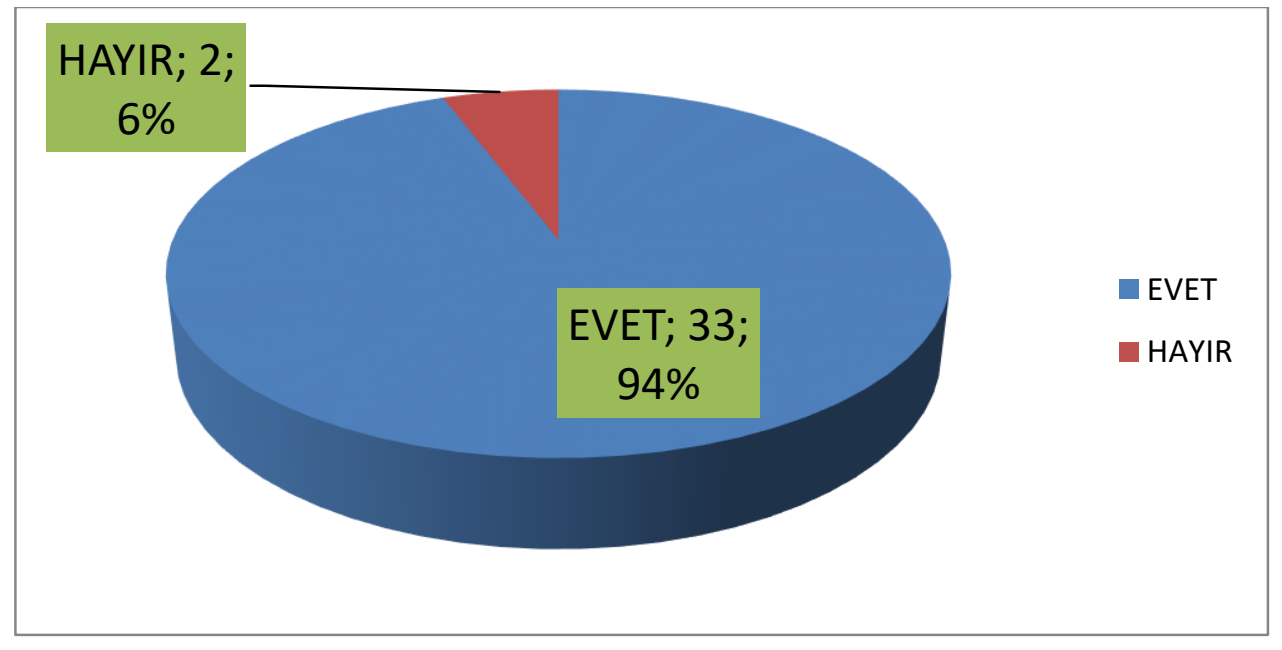

Şekil 9. Program kontenjanları hakkındaki öğrenci yanıtları 
Şekil 9. da mezun sayısının artmasının olumsuz yönde etkisinin olduğunu düşündüğünden, öğrencilerin \%94 ü evet düşürülmelidir yönde görüş belirtmiştir.

10-) Tapu ve Kadastro Teşkilatı ya da LİHKAB (Lisanslı Harita ve Kadastro Büroları)larda mı çalışmak ister misiniz?

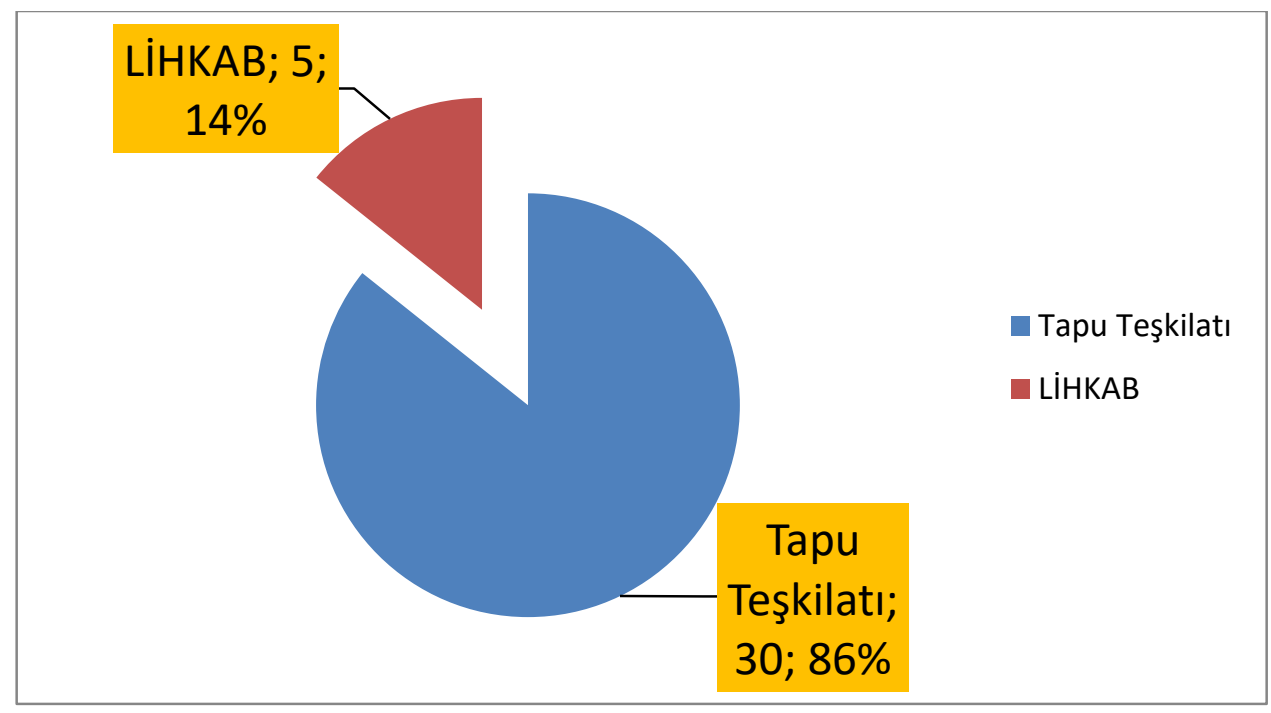

Şekil 10. Program öğrencilerinin en çok çalışmak istedikleri yer yanıtları

Şekil 10. da, öğrencilerin en çok çalışmak istedikleri noktanın, \%86 l1k yanıtta da olduğu gibi Tapu ve Kadastro Müdürlükleri olduğu görülmüştür.

11-) Programların sizce Tapu ve Kadastro, Harita ve Kadastro ya da CBS diye ayrılması doğru mudur?

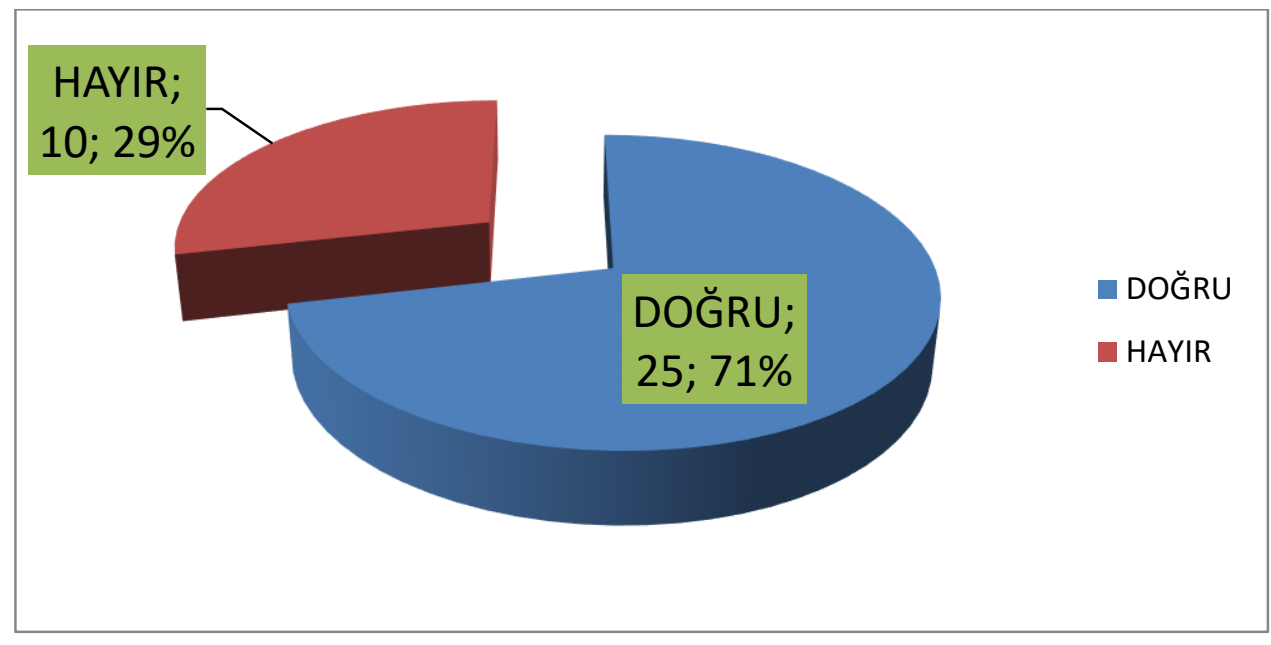

Şekil 11. Aynı anabilim dalından ayrılmaya ilişkin öğrenci yanıtları

Şekil 11. de, harita mühendisliği anabilim dalından ayrılan ve doğan, Tapu, Harita ya da CBS gibi ön lisans programlarının tek çatı altında olmasının doğruluğu ya da yanlışlığı konusundaki soruya öğrencilerin \%71 i evet doğru olarak cevap vermiştir. 
12-) Tapu ve Kadastro programı öğretim elemanlarının, harita mühendisliği dışından, programlarda esas görevli olarak derslere girmesi doğru mudur?

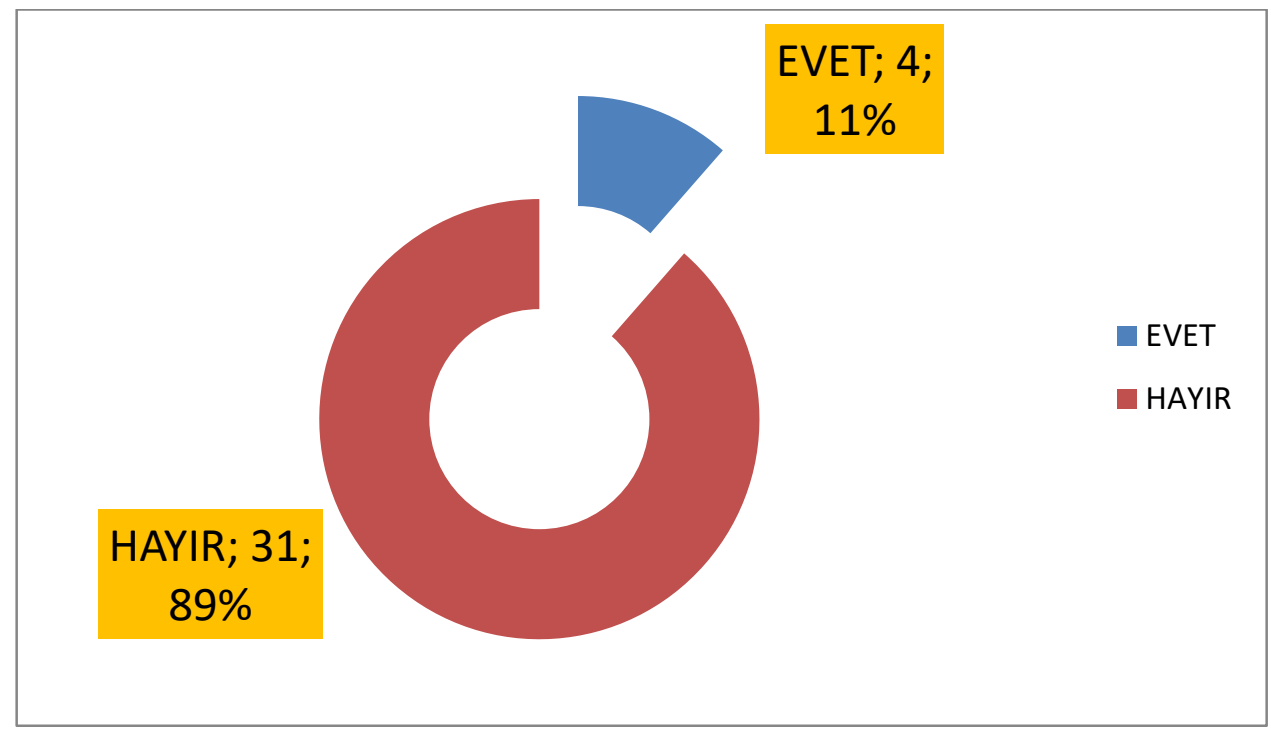

Şekil 12. Öğretim elemanları hakkındaki öğrenci yanıtları

Şekil 12. de, Tapu ve Kadastro programındaki dersler içerik olarak, arazi yönetimi ve kamu ölçmeleri anabilim dalı ağırlıklı olduğundan, ilgili öğretim elemanlarının harita mühendisliği mezunu olması gerektiğinden bu soruda öğrencilere yöneltildiğinden, onlarında \%89 u harita mühendisliği dışından girmesinin doğru olmadığg yanıtını vermiştir.

13-) Ülkedeki meslek yüksekokullarındaki mimarlık ve şehir planlama bölümü ve onun altındaki Tapu ve Kadastro programına gerekli değer, imkan ve araç gereç ihtiyacına cevap veriliyor mu?

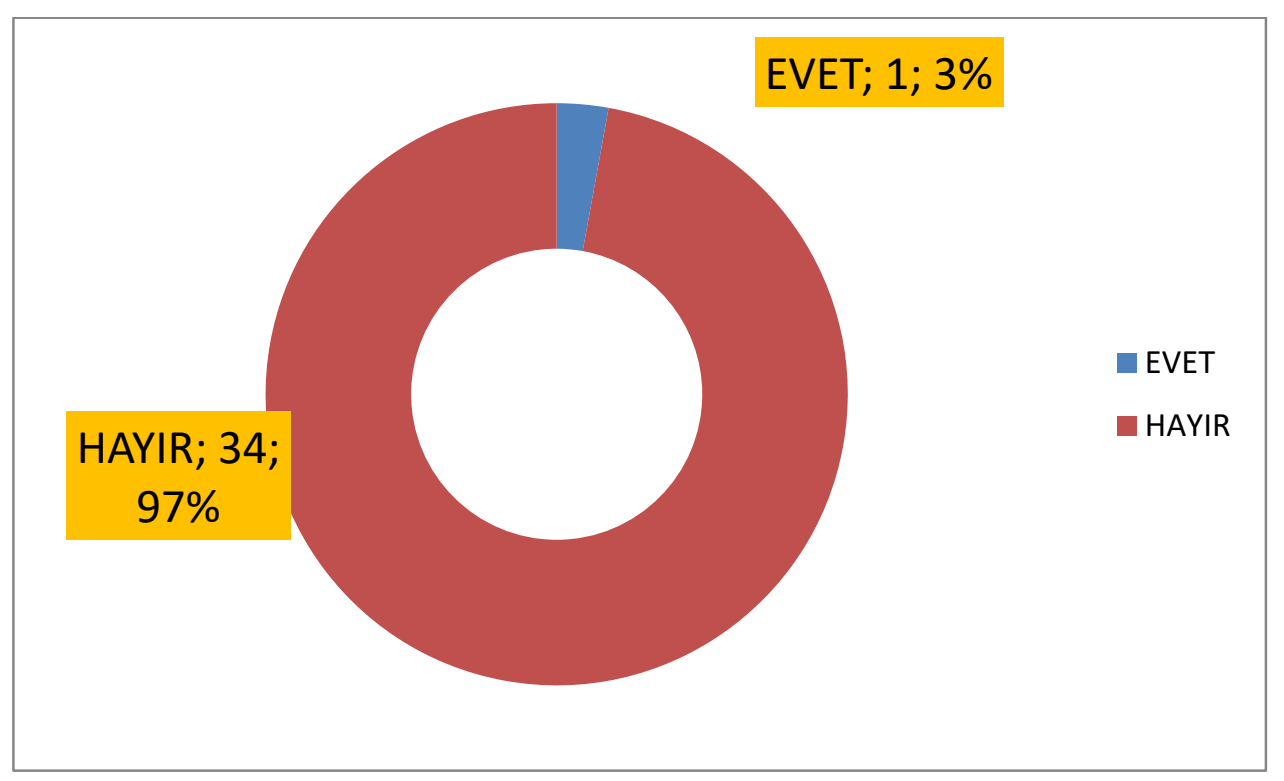

Şekil 13. Programa gerekenlerin yapılıp yapılmaması ile ilgili öğrenci yanıtları 
Şekil 13. de, Ülkedeki meslek yüksekokullarındaki mimarlık ve şehir planlama bölümü ve onun altındaki Tapu ve Kadastro programına gerekli değer, imkân ve araç gereç ihtiyacına cevap veriliyor mu sorusuna öğrencilerin \%97 si hayır cevabını vererek 2 yıllık programlara önem verilmediği düşüncesinde hem fikir olmuştur.

\section{Power (Güç) Analizi ile Örneklem Belirlenmesi}

Güç analizi çalışmalarında gerekli minimum denek sayısını belirleme özellikle Klinik Araştırmalar Etik Kurulu onaylarının zorunluluk haline gelmesinden sonra önemi fark edilmiş bir konudur. Bir çalışmanın planlanma aşamasında yeterli büyüklükteki örneklem genişliğini tahmin etmek gerekir. Gereğinden küçük örnekle çalışmanın sonucu fark bulunabilecek bir araştırmada anlamlı farkı bulamamak bir önemli bir sorundur. Ayrıca gereğinden çok büyük örnek genişliği ile gerçekleştirilen çalışmalarda ise klinik olarak anlamlı olmayan iki uygulamanın istatistiksel olarak anlamlı çıkması mümkündür [6].

Klinik bir çalışmada hipotezler oluşturulurken öncelikle araştırmanın popülasyonu belirlenir ve ardından bu popülasyonu iyi temsil ettiği düşünülen bir örneklem ile çalış1lır. Buradaki amaç elimizdeki örneklemden yararlanarak popülasyon hakkında bir takım kararlar almaktır [7]. Aslında her klinik araştırmada yapılan şey bir bilimsel hipotezi test etmektir. İstatistikte bir hipotezin doğruluğunu test etmek için hipotez takımı oluşturulur. Bu hipotez takımının iki bileşeni vardır [9]. Birincisi Kontrol veya Yokluk hipotezi (H0) olarak bilinir. Bu hipotezde her zaman gruplar arasında fark olmadığı belirtilir. Yokluk hipotezinin içermediği diğer tüm durumları içeren hipoteze ise Alternatif veya Karşıt hipotez (H1) adı verilir [9]. Hipotezler sözel olarak ifade edilebileceği gibi semboller ile de ifade edilebilirler. İki farklı tedavi alan hastaların hastaneden taburcu olma süreleri arasında anlamlı bir fark olup olmadığının karşılaştırılacağı bir çalışma planladığımızı düşünelim. Böyle bir araştırmanın hipotez takımı aşağıdaki gibi olacaktır.

$$
\begin{aligned}
& \text { H0: } \mu \mathrm{A}=\mu \mathrm{B} \\
& \text { H1: } \mu \mathrm{A} \neq \mu \mathrm{B}
\end{aligned}
$$

H0 hipotezinde belirtilen ortalama taburcu olma süreleri bakımından A ve B tedavileri arasında anlamlı bir farklılık olmadığıdır. Bunun alternatifi olan karşıt hipotezde ise anlamlı farklılık olduğu belirtilmektedir. Bir çalışmayı planlama aşamasında araştırmacının aklındaki en önemli sorulardan biri hem klinik hem de istatistiksel olarak anlamlı bir sonuç bulabilmek için en az kaç kişi ile çalışması gerektiğidir [5]. Uygulama 1. İki ortalamanın karşılaştırılması için örnek genişliği belirleme; Tip I hata: 0.05 yada 0.01 düzeyinde olabilir. 0.05 düzeyinde tutmak $\% 95$ güvenle karar vermek demektir. Tip II hata: 0.20 düzeyinde tutulursa testin gücü \%80, 0.10 düzeyinde tutulursa testin gücü \%90 olacaktır. Ortalamalar arasındaki fark (Etki büyüklügü): İki grubun ortalamaları arasında beklenen değişim miktarıdır. Genellikle gruplardan birisi kontrol grubudur. Kontrol grubundaki değerler daha önceki çalışmalardan bulunabilir. Sonrasında yeni grupta bu değerin ne kadar azalacağı veya artacağı tartışılır. Bu farklılık etki büyüklüğü olarak adlandırılır. Grup 1 standart sapma, kontrol grubundaki standart sapma değeri, Grup 2 standart sapma, genellikle kontrol grubuna benzer bir değer girilir [6]. 


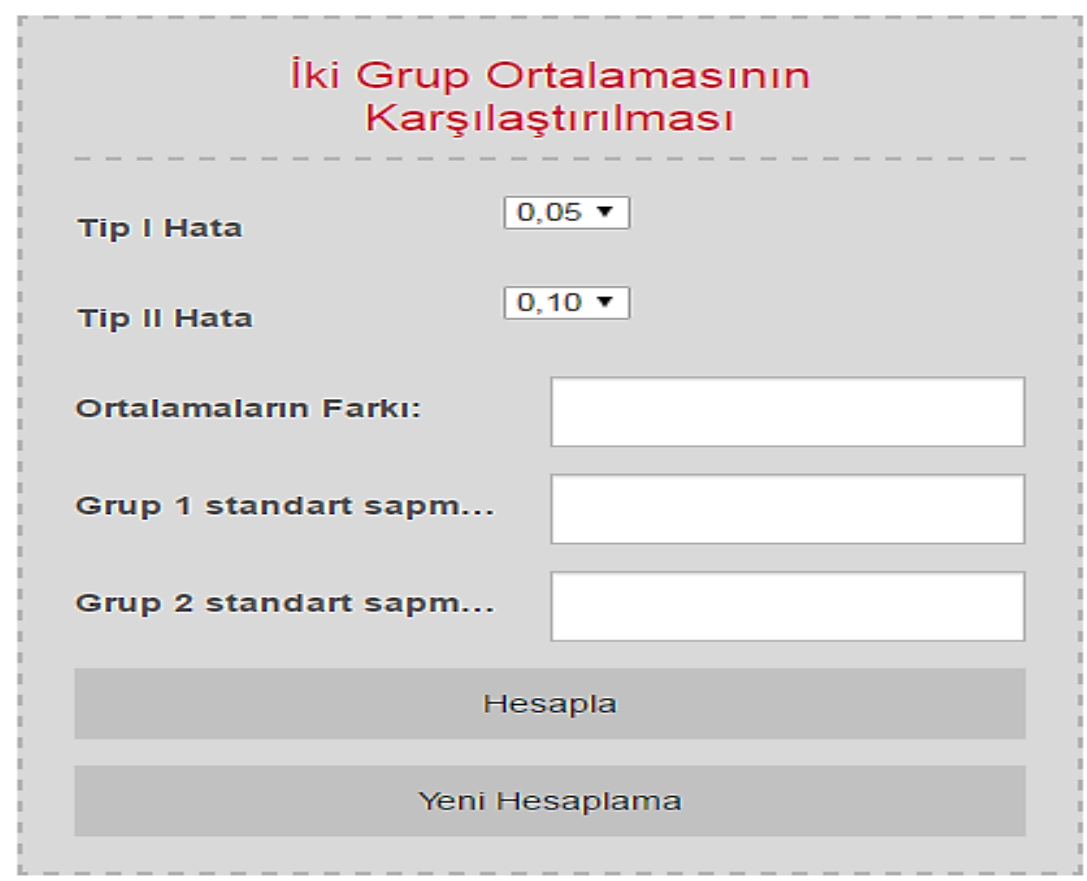

Şekil 14. Power analizi iki grup ortalamasının karşılaştırılması [15].

Uygulama 2. İki oranın karşılaştırılması için örnek genişliği belirleme; Tip I hata: 0.05 ya da 0.01 düzeyinde olabilir. 0.05 düzeyinde tutmak \%95 güvenle karar vermek demektir. Tip II hata: 0.20 düzeyinde tutulursa testin gücü \%80, 0.10 düzeyinde tutulursa testin gücü $\% 90$ olacaktır. 1. grubun oranı: Genellikle kontrol grubunda ya da en bilinen gruptaki oran daha önceki çalışmalardan belirlenir. 2. grubun oranı: Yeni grupta eski gruba bakarak oranın \% ne kadar artacağı ya da azalacağı beklentisi varsa ona göre yeni grup oranının beklenen değeri tahmin edilir [6].

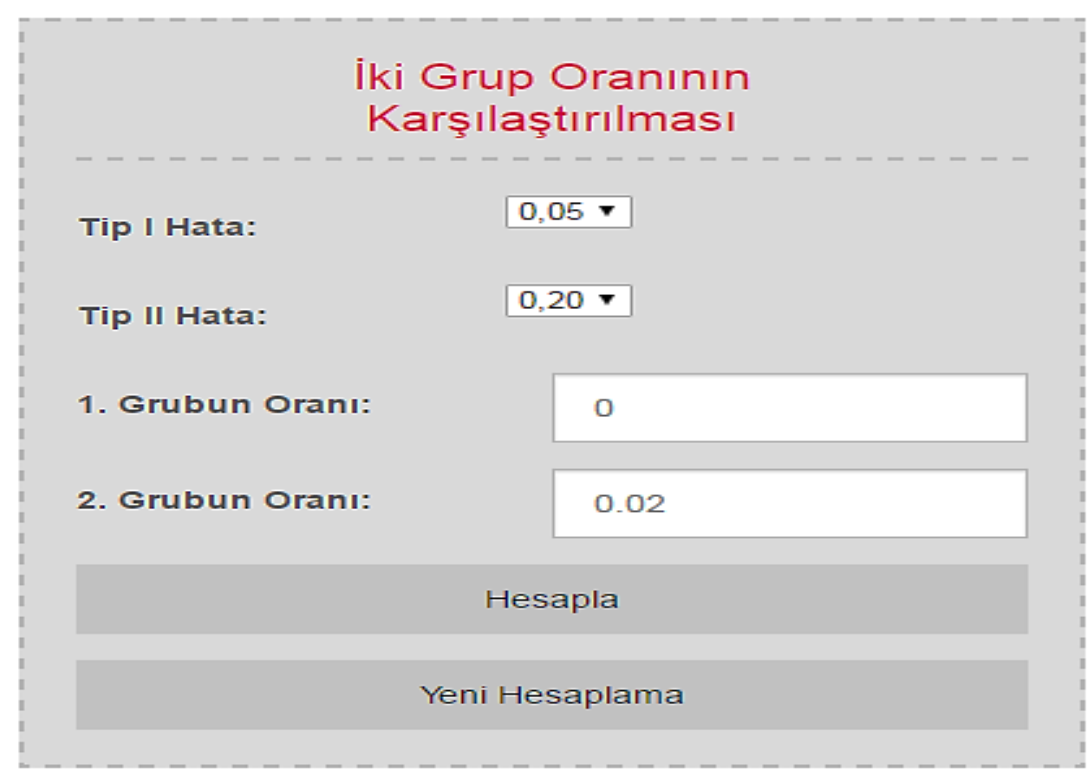

Şekil 15. Power analizi iki grup oranının karşılaştırılması [5]. 
Power (güç) istatistiksel örneklem analizi, yöntem olarak belirlenmiştir. Uygulamada tapu ve kadastro programının ilk öğrenci alımına başladığı 2018-2019 yılı 905 kontenjanı ile 2020-2021 yılı 1230 öğrenci kontenjanı ile kontrol grubunu, 35 kişiden oluşan grup ise deney grubunu meydana getirmiş oldu [11].

Tablo 2. Power testi güven karar verme ve test güven yüzdeleri korelasyonuna denk gelen sayısal gösterim

\begin{tabular}{|c|c|c|c|c|c|c|c|c|}
\hline \multirow[t]{2}{*}{$\begin{array}{l}\text { Power } \\
\text { Analizi }\end{array}$} & \multicolumn{2}{|c|}{$\begin{array}{c}0.05 / 0.10 \\
\text { (905 öğrenci) } \\
\text { Güven/Güç }\end{array}$} & \multicolumn{2}{|c|}{$\begin{array}{c}\text { 0.05/0.10 } \\
\text { (1230 öğrenci) } \\
\text { Güven/Güç }\end{array}$} & \multicolumn{2}{|c|}{$\begin{array}{c}0.05 / 0.20 \\
\text { (905 öğrenci) } \\
\text { Güven/Güç }\end{array}$} & \multicolumn{2}{|c|}{$\begin{array}{c}\text { 0.05/0.20 } \\
\text { (1230 öğrenci) } \\
\text { Güven/Güç }\end{array}$} \\
\hline & 35 kişi & $\begin{array}{l}905 \\
\text { kişi }\end{array}$ & $\begin{array}{c}35 \\
\text { kişi }\end{array}$ & $\begin{array}{c}1230 \\
\text { kişi }\end{array}$ & $\begin{array}{c}35 \\
\text { kişi }\end{array}$ & $\begin{array}{l}905 \\
\text { kişi }\end{array}$ & $\begin{array}{r}35 \\
\quad \mathbf{k i} \\
\text { şi }\end{array}$ & $\begin{array}{l}905 \\
\text { kişi }\end{array}$ \\
\hline $\begin{array}{l}\text { 1.anket } \\
\text { sorusu }\end{array}$ & 18 & 400 & 18 & 615 & 18 & 405 & 18 & 612 \\
\hline $\begin{array}{l}\text { 2.anket } \\
\text { sorusu }\end{array}$ & 28 & 542 & 28 & 952 & 28 & 555 & 28 & 941 \\
\hline $\begin{array}{l}\text { 3.anket } \\
\text { sorusu }\end{array}$ & 32 & 863 & 32 & 1153 & 32 & 888 & 32 & 1100 \\
\hline $\begin{array}{l}\text { 4.anket } \\
\text { sorusu }\end{array}$ & 23 & 798 & 23 & 863 & 23 & 756 & 23 & 841 \\
\hline $\begin{array}{l}\text { 5.anket } \\
\text { sorusu }\end{array}$ & 30 & 820 & 30 & 1196 & 30 & 802 & 30 & 1145 \\
\hline $\begin{array}{l}\text { 6.anket } \\
\text { sorusu }\end{array}$ & 17 & 399 & 17 & 602 & 17 & 406 & 17 & 610 \\
\hline $\begin{array}{l}\text { 7.anket } \\
\text { sorusu }\end{array}$ & 29 & 786 & 29 & 1180 & 29 & 799 & 29 & 1100 \\
\hline $\begin{array}{l}\text { 8.anket } \\
\text { sorusu }\end{array}$ & 18 & 401 & 18 & 605 & 18 & 403 & 18 & 402 \\
\hline $\begin{array}{l}\text { 9.anket } \\
\text { sorusu }\end{array}$ & 33 & 896 & 33 & 1200 & 33 & 723 & 33 & 1142 \\
\hline $\begin{array}{l}\text { 10.anket } \\
\text { sorusu }\end{array}$ & 30 & 865 & 30 & 1189 & 30 & 852 & 30 & 1100 \\
\hline $\begin{array}{l}\text { 11.anket } \\
\text { sorusu }\end{array}$ & 25 & 752 & 25 & 1020 & 25 & 742 & 25 & 1000 \\
\hline $\begin{array}{l}\text { 12.anket } \\
\text { sorusu }\end{array}$ & 31 & 890 & 31 & 1185 & 31 & 852 & 31 & 1001 \\
\hline $\begin{array}{l}\text { 13.anket } \\
\text { sorusu }\end{array}$ & 34 & 902 & 34 & 1223 & 34 & 900 & 34 & 1145 \\
\hline
\end{tabular}


Son iki yılın öğrenci kontenjanları ile ankete katılan öğrenci sayısının güven aralığı yüzde 5 ve güç aralığı yüzde 90 ile 80 sınırlaması yapılarak yaklaşı olarak tüm tapu ve kadastro programları öğrencilerinin 13 soruya anlamlılığı sayı ifadesi olarak anlaşılmaya çalışıldı.

\section{SONUÇ ve ÖNERILER}

Ülkemizde meslek yüksekokullarında, mimarlık ve şehir planlama ismi altında Tapu ve Kadastro programları, 2019-2020 eğitim öğretim yıllarında 13 üniversitede yaklaş1k 905 öğrenci ile faaliyetlerini sürdürüp, 2020-2021 eğitim öğretim yılında 26 üniversite 1230 öğrenci ile devam etti. Atanma ve iş bulma imkanı şimdilik kolay olduğundan, program öğrenci kontenjanları dolmuştur. Tapu ve Kadastro programı memurluk alımı, 2018 KPSS ile ortalama 77 puan civarında kapattı̆̆ından memuriyete girme şansı var olduğundan popüleritesini korumaktadır. Faal olarak 35 öğrencisi olan, Artvin Çoruh Üniversitesi, Artvin Meslek Yüksekokulu Ardanuç Tapu ve Kadastro programında uygulanan 13 soruluk özet şeklindeki sorular ile mahallî olarak doneler tespit edildi. Program hakkındaki her şey, öğrencilerin görüşleri de alınarak, programın nerde olduğu ve zamanla nereye gideceği tespit edilmeye çalışıldı. 35 öğrencinin seviyesi, yaşı, bilgi birikimi göz önüne alındığında, 35 kişinin görüşleri kısmi olarak, son iki yılın 905 ve 1230 öğrenci kontenjanına karşılık, güç testiyle yaklaşık kaç kişinin görüşlerini yansıtacağı tahmin edildi. Anket çalışmasından da anlaşılacağı üzere, öğrencilerin meslek hakkında pek bilgileri yoktur. Kolay şekilde iş imkânı olduğunu düşündüklerinden, mesleki seçmiştirler. Meslek 2-3 yıl öncesine kadar, mezun sayısı daha az olduğundan, mezunlar daha rahat işe girmekteyken, günümüzde bu oran daha aza inmiştir. Diğer tüm bölüm ve programlarda olduğu gibi, kontenjanların azaltılıp, yeni noktalara açılmaların önüne geçilip, ancak bu yığılmaların eritilmesiyle her bölüm ve programda olduğu gibi Tapu ve Kadastro programı da güncelliğini muhafaza edebilir.

\section{REFERANSLAR}

[1] Artvin Çoruh Üniversitesi, Ardanuç Tapu ve Kadastro Programı Öğrencileri, 2020

[2] Cihangir Ö. (2011). Türkiye'de sağlık teknikerliği ön lisans eğitiminin standardizasyonu. Sağlık ve Toplum, 21(2), 3-8.

[3] Erkal, S.İ, Yalçın, A.S., Sancar, B. (2012). Ankara Üniversitesi, Sağlık Bilimleri Fakültesi öğrencilerinin ebelik ve hemşirelik bölümlerini seçme nedenleri. ankara sağllk bilimleri dergisi, 1(1), 73-90.

[4] Gündüzalp Seda, Gönül Şener, MESLEK YÜKSEKOKULU ÖĞRENCILERININ KARIYER TERCIHLERİ, International Engineering and Natural Sciences Conference (IENSC 2018), Nov. 2018

[5] KLINIKK ARAŞTIRMALARDA ÖRNEK GENIŞLIĞİ BELIRLEME (SAMPLE SIZE DETERMINATION FOR CLINICAL RESEARCH) Dr. Seval Kul,Gaziantep Üniversitesi Tıp Fakültesi, Biyoistatistik ve Tıp Bilişimi Anabilim Dalı, Gaziantep, Türkiye (doi:10.5152/pb.2011.11)

[6] Kul S., (2011), Klinik araştırmalarda örnek genişliği belirleme, Doktora Tezi, Gaziantep Üniversitesi Sağlık Bilimleri Ensitüsü Biyoistatistik ve Tıp Bilişimi Anabilim Dalı, Gaziantep.

[7] Simon SD. Statistical Evidence in Medical Trials, What Do the Data Really Tell Us?Oxford: Oxford press: 2006; $138-41$

[8] Smoller SW. Biostatistics and epidemiology, a primer for health and biomedical professionals, Newyork: Springer;2003; 153-7.

[9] Sümbüloğlu K, Sümbüloğlu V, Biyoistatistik, 11.bask1, Ankara: 2005; 49-52.

[10] Taşkaya, S., Sesli, F.A., International Journal of Eastern Anatolia Science Engineering and Design ( IJEASED) (2019) 1(1):1-13 
\{11] Taşkaya, S., Sesli, F.A., Elazığ İli Mevcut Stratejik Gürültü Haritalarının Anket Çalışması İle İrdelenmesi 445 Journal of Urban Academy | Volume: 11 Issue: 3 | ISSN: 2146-9229

[12] URL-1: https://tkgm.gov.tr/tr

[13] URL-2: https://myo.artvin.edu.tr/tapu-ve-kadastro-ardanuc

[14] URL-3: https://www.basarisiralamalari.com/tapu-ve-kadastro-2-yillik-2021-taban-puanlari-ve-basarisiralamalari/

[15] URL-4, (2019), Kul S., İstatistiksel Analiz, Power analiz programı ile örnekleme hesaplama, Güç analizi, http://www.p005.net/analiz/guc-analizi [Erişim 30 Nisan 2019]. 